\title{
Life Cycle Assessment of Cement Production with Marble Waste Sludges
}

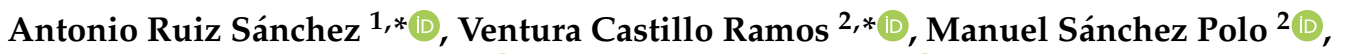 \\ María Victoria López Ramón ${ }^{3}$ and José Rivera Utrilla ${ }^{2}$ (D) \\ 1 Department of Structure Mechanics and Hydraulic Engineering, University of Granada, 18071 Granada, Spain \\ 2 Department of Inorganic Chemistry, Faculty of Science, University of Granada, 18071 Granada, Spain; \\ mansanch@ugr.es (M.S.P.); jrivera@ugr.es (J.R.U.) \\ 3 Department of Inorganic and Organic Chemistry, Faculty of Experimental Science, University of Jaén, \\ 23071 Jaén, Spain; mvlro@ujaen.es \\ * Correspondence: antonioruiz@ugr.es (A.R.S.); vcastillo@ugr.es (V.C.R.)
}

Citation: Sánchez, A.R.; Ramos, V.C.; Polo, M.S.; Ramón, M.V.L.; Utrilla, J.R. Life Cycle Assessment of Cement Production with Marble Waste Sludges. Int. J. Environ. Res. Public Health 2021, 18, 10968. https:// doi.org/10.3390/ijerph182010968

Academic Editor: Paul B. Tchounwou

Received: 27 August 2021

Accepted: 16 October 2021

Published: 19 October 2021

Publisher's Note: MDPI stays neutral with regard to jurisdictional claims in published maps and institutional affiliations.

Copyright: (c) 2021 by the authors. Licensee MDPI, Basel, Switzerland. This article is an open access article distributed under the terms and conditions of the Creative Commons Attribution (CC BY) license (https:// creativecommons.org/licenses/by/ $4.0 /)$.
Abstract: The construction industry has a considerable environmental impact in societies, which must be controlled to achieve adequate sustainability levels. In particular, cement production contributes $5-8 \%$ of $\mathrm{CO}_{2}$ emissions worldwide, mainly from the utilization of clinker. This study applied Life Cycle Assessment (LCA) methodology to investigate the environmental impact of cement production and explore environmental improvements obtained by adding marble waste sludges in the manufacture of Portland cement. It was considered that $6-35 \%$ of the limestone required for its production could be supplied by marble waste sludge (mainly calcite), meeting the EN 197-1:2011 norm. Energy consumption and greenhouse gas (GHG) emission data were obtained from the Ecovent database using commercial LCA software. All life cycle impact assessment indicators were lower for the proposed "eco-cement" than for conventional cement, attributable to changes in the utilization of limestone and clinker. The most favorable results were achieved when marble waste sludge completely replaced limestone and was added to clinker at $35 \%$. In comparison to conventional Portland cement production, this process reduced GHG emissions by $34 \%$, the use of turbine waters by $60 \%$, and the emission of particles into the atmosphere by $50 \%$. Application of LCA methodology allowed evaluation of the environmental impact and improvements obtained with the production of a type of functional eco-cement. This approach is indispensable for evaluating the environmental benefits of using marble waste sludges in the production of cement.

Keywords: marble waste sludge; life cycle assessment (LCA); $\mathrm{CO}_{2}$; emissions; greenhouse gases (GHG); cement; limestone; environment

\section{Introduction}

Worldwide cement production has remained constant since the crisis in 2008, reaching 4100 million metric tons in 2019 [1] (Figure S1). According to the latest International Energy Agency report, global cement production is expected to be $12 \%$ higher by 2050 , with an increase of $4 \%$ in direct $\mathrm{CO}_{2}$ emissions [2].

The cement industry has been reported to contribute $5-8 \%$ of global $\mathrm{CO}_{2}$ emissions [3,4], estimated at $1.50 \pm 0.12$ gigatons of $\mathrm{CO}_{2}$ in 2018 [5]. The calcination process contributes half of the $\mathrm{CO}_{2}$ emitted [6,7], with the emission of $850 \mathrm{~kg} \mathrm{CO}_{2}$ per ton of clinker produced [8].

The $\mathrm{CO}_{2}$ emitted during clinker production derives from the combustion of fossil fuels to generate thermal energy and includes $\mathrm{CO}_{2}$ from the decomposition of $\mathrm{CaCO}_{3}$ into $\mathrm{CaO}$ and from the calcination process (limestone decarbonation) [9]. The latest update of the Cement Sustainability Initiative (CSI) database estimates the emission of $836 \mathrm{~kg} \cdot \mathrm{CO}_{2} / \mathrm{t}$ clinker in 2018 , based on data from $21 \%$ of the world's cement plants, lower than the rate of $844 \mathrm{~kg} \cdot \mathrm{CO}_{2} / \mathrm{t}$ clinker recorded in 2015 [10]. It was reported that 12,700,000 tons of clinker 
were produced in Spain in 2018, based on data from 63\% of cement production plants, with the emission of $11,100,000$ tons of $\mathrm{CO}_{2}$ [11]. Indirect $\mathrm{CO}_{2}$ emissions attributable to cement production result from the production of electric energy and from transportation and logistics.

According to Schneider [12], the greatest potential $\mathrm{CO}_{2}$ reduction potential can be achieved by replacing clinker with supplementary cementitious materials that deliver the appropriate performance and durability, which need to be readily available. Efforts to reduce $\mathrm{CO}_{2}$ emissions from cement production should focus not only on the calcination process but also on the processes responsible for the other $50 \%$ of emissions. Account should also be taken of the impact on the consumption of raw materials (limestone, clay, etc.), with 1.7 tons being needed to produce 1 ton of clinker [8]. The substitution of $40 \%$ of the clinker used in cement production could theoretically reduce the annual global emission of $\mathrm{CO}_{2}$ by up to 400 million tons.

In the 2015 Paris Agreement, the European Union (EU) committed to a $40 \%$ reduction in greenhouse gas (GHG) emissions versus 1990 levels by 2030 [13]. The European cement industry is governed by Directive 2003/87/CE, which assigns maximum $\mathrm{CO}_{2}$ emissions by sector and calculation method (emission rights) and sets out the instruments available to comply with the reductions agreed by each member State.

Potential environmental improvements investigated include reductions in the consumption of fossil fuels and raw materials, atmospheric emissions, effluent discharges, and solid waste associated with conventional Portland cement production.

Researchers have frequently characterized and studied the properties of cements and mortars with marble waste sludge over the past few years [14-23]. However, they have centered on the fulfillment of norms for mechanical composition and resistance (AENOR, 2005; AENOR, 2011) and have not addressed the issue of marble waste utilization from the perspective of environmental improvements. Some have referred to reductions in the carbon footprint achieved with additives $[24,25]$ through a lesser consumption of cement clinker, but they have not presented the environmental argument.

Life cycle assessment (LCA) methodology was internationally formalized and standardized within the family of ISO 14,040 standards in the 1990s, with a broad revision in 2006. It is widely accepted by researchers and institutions and used by public administrations to formulate policies [26]. LCA offers the quantification of environmental pressures related to goods and services throughout their life cycle, including the acquisition, treatment, configuration, production, and use of raw materials and their recycling or final disposal, i.e., "from the cradle to the grave".

The regulations establish four phases of LCA development: (i) definition of the objective and scope, including limits of the system and levels of detail; (ii) life cycle inventory (LCI) analysis, compiling and quantifying inputs and outputs throughout the life cycle of the product $[27,28]$; (iii) life cycle impact assessment (LCIA), determining and evaluating the magnitude and significance of the potential environmental impact of the product [29]; and (iv) interpretation of LCI and/or/LCIA findings, establishing conclusions and making recommendations.

Besides LCA, other environmental management techniques include risk evaluation, environmental performance evaluation, system dynamics, environmental audit, ecological footprint, GHG protocol, and LCIA. LCA is considered to provide the optimal framework for evaluating the potential environmental effects of products, and it has been used in research on waste, demonstrating that its environmental impact is a key question to be addressed [30,31].

Introduced by Jay Forrester in the 1960s, system dynamics is useful to understand complex large-scale management problems in accordance with the principles of systemic thinking [32]. The difference between LCA and system dynamics lies in their scope. Thus, LCA has a more limited scope, focusing on very specific environmental indicators, which should not be perceived as a drawback but rather as a mark of its specificity. An et al. [33] used LCA to compare various scenarios of cement production and $\mathrm{CO}_{2}$ capture. Although 
they found that some technological changes only minimally reduce the environmental impact of each ton of cement, they can have a major effect if applied throughout the cement sector, as noted by multiple researchers. The review by Wu et al. [34] concluded that LCA prevails over system dynamics. Nicoara et al. [35] evaluated the contribution of industrial waste, including marble powder, as supplementary cementitious material in cement manufacturing. After a wide review, they emphasized the importance of LCA alongside investigation of the mechanical and physicochemical properties of the material in order to establish the environmental feasibility of its utilization.

Table 1 lists the most recent investigations that used LCA methodology in relation to cement, mortar, and concrete products, either directly or within research on waste from construction and demolition. Few published studies have used LCA to assess the contribution of industrial additives or byproducts to cement and/or concrete, presented as complementary to technical evaluations. The table shows wide variations in the utilization and applicability of LCA among researchers. The method is frequently adapted to the aims of the investigation, which is a valid approach, although its principles, requirements, and guidelines have sometimes been followed in a rather relaxed manner. The review by Gursel et al. [27] highlights the need to continue quantitative research on the utilization of industrial additives and byproducts in concrete production, while Brito and Kurda 2021 [23] reviewed a series of potential strategies to reduce the negative impact of cement-based materials production.

The Global Warming Potential (GWP) of these processes is frequently evaluated in the aforementioned studies. It has been estimated that Portland cement production generates an average of $842 \mathrm{~kg} \cdot \mathrm{CO}_{2} /$ ton of clinker produced and that around $6-7 \%$ of total anthropogenic GHG emissions derive from cement production. In order to achieve the agreed objective of a $50 \%$ reduction in total $\mathrm{CO}_{2}$ emissions by 2050, $\mathrm{CO}_{2}$ emissions from the cement industry need to be reduced by at least $18 \%$ [36].

The present study addresses the reduction of $\mathrm{CO}_{2}$ emissions in cement manufacturing by the utilization of marble waste byproducts and is therefore within the framework of Mechanisms of Clean Development, alongside different publications from a business management perspective [25]. LCA methodology is used in the present manuscript to evaluate environmental improvements in conventional Portland cement manufacturing that can be achieved by introducing marble waste sludge into its production. Account is also taken of the environmental benefit of eliminating marble waste from the mining industry, which is currently deposited in decantation pools as inert material, representing an environmental hazard.

Table 1. Applications of LCA for materials used in the production of cement, mortar, and concrete.

\begin{tabular}{|c|c|c|c|c|c|}
\hline Material & Parameters Analyzed * & $\mathrm{GHG}^{* *}$ & Functional Unit & Stages Considered & Ref. \\
\hline $\begin{array}{c}\text { Cement production in } \\
\text { Spain }\end{array}$ & $\begin{array}{c}\text { ADP, GWP, ODP, HTP, } \\
\text { TETP, POCP, AP, EP, } \\
\text { MEP, LUP }\end{array}$ & $21.6 \%$ & 1 ton of grey cement & $\begin{array}{l}\text { Cement production. } \\
\mathrm{CO}_{2} \text { capture }\end{array}$ & [37] \\
\hline $\begin{array}{l}\text { Cement with } \\
\text { cementitious powder } \\
\text { waste }\end{array}$ & GWP & Variable & - & Cement production & [38] \\
\hline $\begin{array}{l}\text { Cement production in } \\
\text { China }\end{array}$ & $\begin{array}{c}\text { GWP, AP, EP, POCP, } \\
\text { HTP }\end{array}$ & - & $\begin{array}{l}1 \text { ton of cement and } \\
\text { with } 42.5 \mathrm{MPa}\end{array}$ & $\begin{array}{l}\text { Material acquisition. } \\
\text { Processing and } \\
\text { transportation to plant. } \\
\text { Cement production }\end{array}$ & [39] \\
\hline $\begin{array}{l}\text { Substitution of cement } \\
\text { in concrete with } \\
\text { supplementary } \\
\text { cementing materials }\end{array}$ & GWP & Variable & $1 \mathrm{~m}^{3}$ of concrete & $\begin{array}{l}\text { Material acquisition. } \\
\text { Transportation to plant. } \\
\text { Concrete production. } \\
\text { Final transportation }\end{array}$ & [40] \\
\hline
\end{tabular}


Table 1. Cont.

\begin{tabular}{|c|c|c|c|c|c|}
\hline Material & Parameters Analyzed * & $\mathrm{GHG}^{* *}$ & Functional Unit & Stages Considered & Ref. \\
\hline $\begin{array}{l}\text { Mixtures of concrete } \\
\text { with blast furnace fly } \\
\text { ash and slag }\end{array}$ & GWP & $\begin{array}{l}32 \% \\
62 \%\end{array}$ & $1 \mathrm{~m}^{3}$ of concrete & $\begin{array}{l}\text { Material acquisition. } \\
\text { Transportation to plant. } \\
\text { Concrete production. } \\
\text { Final transportation }\end{array}$ & [41] \\
\hline $\begin{array}{l}\text { Self-compacting } \\
\text { concrete }\end{array}$ & GWP & - & $\begin{array}{c}1 \mathrm{~m}^{3} \text { of premixed } \\
\text { concrete }\end{array}$ & Premixed & [42] \\
\hline Cement with additives & GWP, EC & $12 \%$ & 1 ton of cement & $\begin{array}{l}\text { Material acquisition. } \\
\text { Processing and } \\
\text { transportation to plant. } \\
\text { Cement production. }\end{array}$ & [43] \\
\hline $\begin{array}{l}\text { Construction product } \\
\text { recycling }\end{array}$ & GWP & - & $\begin{array}{l}\text { Cement production } \\
\text { demand. Reference } \\
\text { flow }\end{array}$ & $\begin{array}{l}\text { Landfill. Downstream } \\
\text { recycling. Recycling. } \\
\text { Recycling after selective } \\
\text { demolition }\end{array}$ & [44] \\
\hline $\begin{array}{l}\text { Concrete with ash } \\
\text { from wastewater } \\
\text { treatment plant } \\
\text { sludges }\end{array}$ & $\begin{array}{l}\text { ADP, GWP, ODP, HTP, } \\
\text { TETP, POCP, AP, EP }\end{array}$ & $9 \%$ & $\begin{array}{c}1 \mathrm{~m}^{3} \text { of premixed } \\
\text { concrete }\end{array}$ & $\begin{array}{l}\text { Transportation and } \\
\text { premixing }\end{array}$ & [45] \\
\hline $\begin{array}{c}\text { Cement with granite } \\
\text { sludges }\end{array}$ & EC & - & - & Test tube preparation & [46] \\
\hline $\begin{array}{l}\text { Cement mortars with } \\
\text { plastic waste and } \\
\text { carbon fibers }\end{array}$ & GWP, EC & $13.69 \%$ & $1 \mathrm{~m}^{3}$ of cement paste & Cement production & [47] \\
\hline $\begin{array}{l}\text { Self-compacting } \\
\text { concrete reducing } \\
\text { binding material }\end{array}$ & GWP & $16 \%$ & $\begin{array}{c}1 \mathrm{~m}^{3} \text { of premixed } \\
\text { concrete }\end{array}$ & Concrete production & [48] \\
\hline $\begin{array}{l}\text { Cement mortar with } \\
\text { glass powder }\end{array}$ & $\begin{array}{l}\text { GWP, ODP, AP, EP, } \\
\text { POCP }\end{array}$ & $20 \%$ & 100 bags of cement & Cement production & [49] \\
\hline $\begin{array}{l}\text { Concrete reducing } \\
\text { cement, adding } \\
\text { metakaolin and steel } \\
\text { fibers }\end{array}$ & GWP & Variable & $\begin{array}{c}1 \mathrm{~m}^{3} \text { of premixed } \\
\text { concrete }\end{array}$ & $\begin{array}{l}\text { Obtaining raw material } \\
\text { Fresh concrete production. } \\
\text { Transportation }\end{array}$ & [50] \\
\hline $\begin{array}{c}\text { Ornamental stone } \\
\text { waste added to cement }\end{array}$ & GWP, EC & $9 \%$ & $1 \mathrm{~kg}$ of product & $\begin{array}{l}\text { Additive drying. } \\
\text { Cement production. } \\
\text { Transportation }\end{array}$ & [51] \\
\hline
\end{tabular}

* ADP: antibiotic depletion potential. GWP: global warming potential. ODP: ozone layer depletion potential, R11-CCl3 F. HTP: human toxicity potential, DCB-1,4- dichlorobenzene. TETP: terrestrial ecotoxicity potential. POCP: Photochemical ozone creation potential. AP: Acidification potential. EC: Energy consumption. EP: Eutrophication potential. MEP: Marine Eutrophication potential. LUP: Land-use potential. ** $\mathrm{GHG}=$ greenhouse gas emissions. The researchers use different terms for the same concept, e.g.,: $\mathrm{KgCO}_{2}$, carbon footprint, climate change, GWP, etc.

\section{Materials and Methods}

\subsection{Marble Waste Sludges}

The waste used in this study is sludge from the marble processing industry in the province of Almeria (Spain). It derives from the refrigeration process applied in the cutting and polishing of marble blocks and slabs, with the water being extracted by centrifugation and the remaining sludge deposited in a public decantation pool. The sludge is an inert waste, largely comprising calcite, with alkaline $\mathrm{pH}$ and particle size $<1 \mu \mathrm{m}$. Sludge samples were gathered at a distance of $100 \mathrm{~km}$ from the factory where the clinker and cement was prepared. The technological validity of this proposal was examined by using the sludge samples to prepare six CEM II cements that fulfill European norm EN 197-1, increasing the proportion of sludge and reducing the percentage of clinker. Studies have confirmed the viability of this approach for the production of mixed cement [52]. 
The simultaneous adoption of these strategies in the concrete industry would reduce its environmental impact.

\subsection{Study Strategies for Reducing Environmental Impacts}

This study proposes three strategies to reduce the environmental impact of the cement industry based on the utilization of alternative raw materials and the application of LCA methodology, as described below and summarized in Figure 1:

I. Utilization of carbonated sludge as substitute for raw materials used to produce cement clinker, maintaining composition percentages.

II. Utilization of carbonated sludge as additive, reducing the percentage clinker in cement (by weight) to obtain CEM-II cement.

III. Utilization of carbonated sludge to replace the raw materials that form the clinker, obtaining CEM-II cements with different proportions of carbonated sludge.

We have found no other published environmental and cost-benefit analyses of the use of waste powders in large-scale production, as also reported by other authors [53]. Besides replacing limestone with marble waste powder, other stages of conventional Portland cement manufacturing are affected by the present proposal, including the obtaining and transformation of raw materials and the preparation of the raw cement and cement. Schneider et al. [54] described different strategies for promoting sustainability in the cement industry, including the utilization of alternative fuels and raw materials. The present study focuses on the substitution of raw materials and the reduction in clinker.

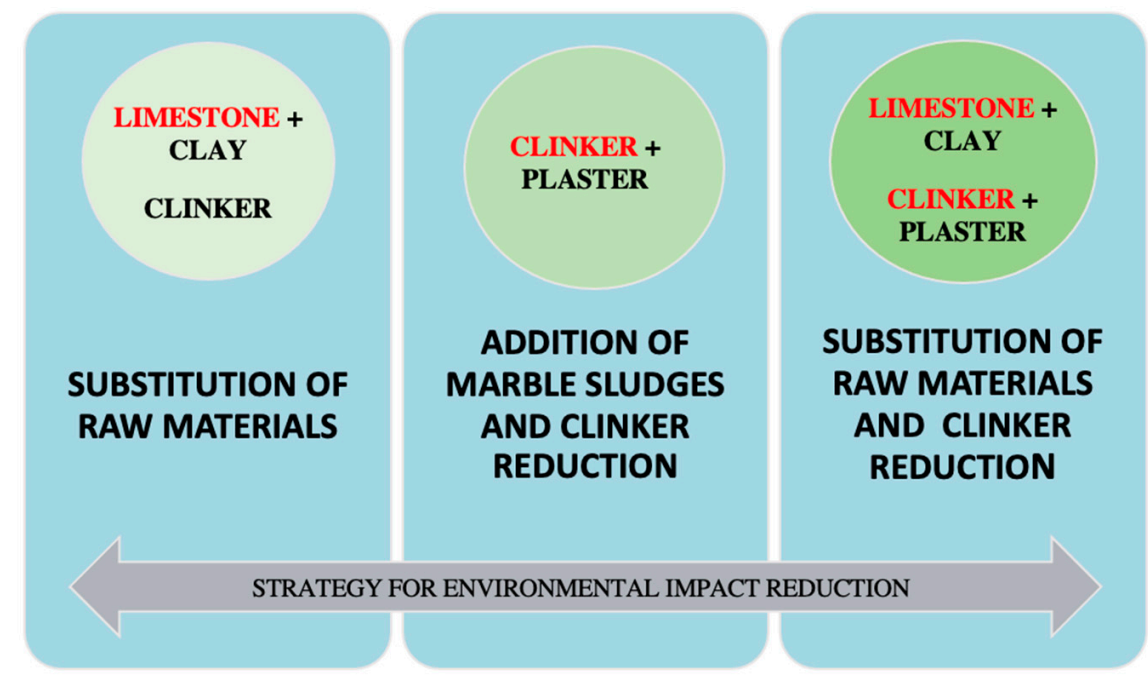

Figure 1. Diagram of the strategy to reduce the environmental impact of the cement industry by using carbonated sludge waste.

\subsection{Scope, System Boundary, and LCA Methodology}

\subsubsection{Scope of the Study}

The present study aims to assess and compare the environmental impact of Portland cement production and the derived "eco-cement" produced with marble wastes, applying LCA methodology focusing on the category of environmental impact of Climate Change or Global Warming Potential (GWP).

\subsubsection{Functional Unit}

The functional unit is defined as $1 \mathrm{~kg}$ of cement at the factory gate. This study adopts a "cradle-to-gate" approach, so that the inventory includes processes associated with the production of these services. Sludge is generated in a process that classifies it as waste and does not therefore take account of its environmental burden. The problem with adopting a "cradle-to-grave" or "cradle-to-cradle" perspective is the lack of representative data related 
to the phases of use and end of useful life. The database for the life cycle inventory in the construction industry includes cement, aggregates, and water as examples of primary input materials, but it does not specifically include data on supplementary cementitious materials or recycled waste [55].

The setting of the functional unit is established, defining the quantification of the identified functions (performance characteristics) of the product [56]. This is important because it limits the concepts considered and quantified, it provides input and output data for the process, and, more importantly, it allows comparisons of LCA results among processes or products with the same functional performance. ISO 14,040 standard and 14,044 methodology were used for the purposes of this evaluation, which aimed to establish a framework rather than detailed guidelines. LCA studies need to use the same parameters for their functional units to permit their comparison. In this way, the ISO standard organizes the LCA into four main phases:

I. Definition of the objectives and scope, making key decisions on the configuration and definition of the system under study.

II. Inventory analysis, identifying and quantifying the energy, water, and materials used and environmental emissions, including solid waste, gas emissions, and wastewater discharge.

III. Evaluation of the LCIA to identify and assess the amount and importance of potential environmental impacts. Inputs and outputs are first assigned to impact categories, and their potential impacts are quantified according to characterization factors. This step provides details on the indicators resulting from all impact categories; the importance of each impact category is evaluated by normalization and, finally, by weighting.

IV. The last phase comprises the interpretation and review of results, determination of data sensitivity, and presentation of conclusions.

\subsubsection{System Boundary}

Figure 2 summarizes the system limits, including all of the supplies necessary for cement production. They cover the extraction of each raw material, its preparation and homogenization for producing raw cement, and its transportation. The raw cement is burned to obtain clinker, followed by milling and the addition of plaster. The final product is stored in bulk in the plant facilities.

Industrial machinery and equipment are not considered, because of the difficulty of inventorying all goods involved and because the environmental impact per product unit is considered low in the LCA framework in comparison to the other processes, being used over a prolonged time period and also in other processes.

The Portland cement production process and associated norms need to be summarized, taking EN 197-1 regulation as reference, in order to develop a strategy to reduce the environmental impact by using marble waste in powder form.

The process is divided into four phases (Figure 2): (I) Preparation and transport of raw materials, obtaining the limestone, clay, sand, and iron mineral in the quarry, grinding them, and then transporting them to the plant; (II) Raw material processing, homogenizing components by selective grinding and mixing, producing raw cement; (III) Clinker production; burning the raw cement, which is usually preheated; and (IV) Milling of clinker and additives; after cooling, plaster and other additives are added to the clinker, and the resulting mixture is milled. The final product, ordinary Portland cement, is then stored for subsequent distribution.

Finally, it should also be considered that the system suggested is for full-scale production and that cement is an essential component of two products heavily used in construction worldwide, i.e., concrete and mortar. Some studies report that Portland cement is the main source of $\mathrm{CO}_{2}$ emissions in concrete mixtures, reaching $81 \%$ of total $\mathrm{CO}_{2}$ emissions [57], and concrete has become the second most widely used substance in the world after water [58]. 
The designations of ordinary Portland cements and those with additives are listed in supplementary information (Table S1).

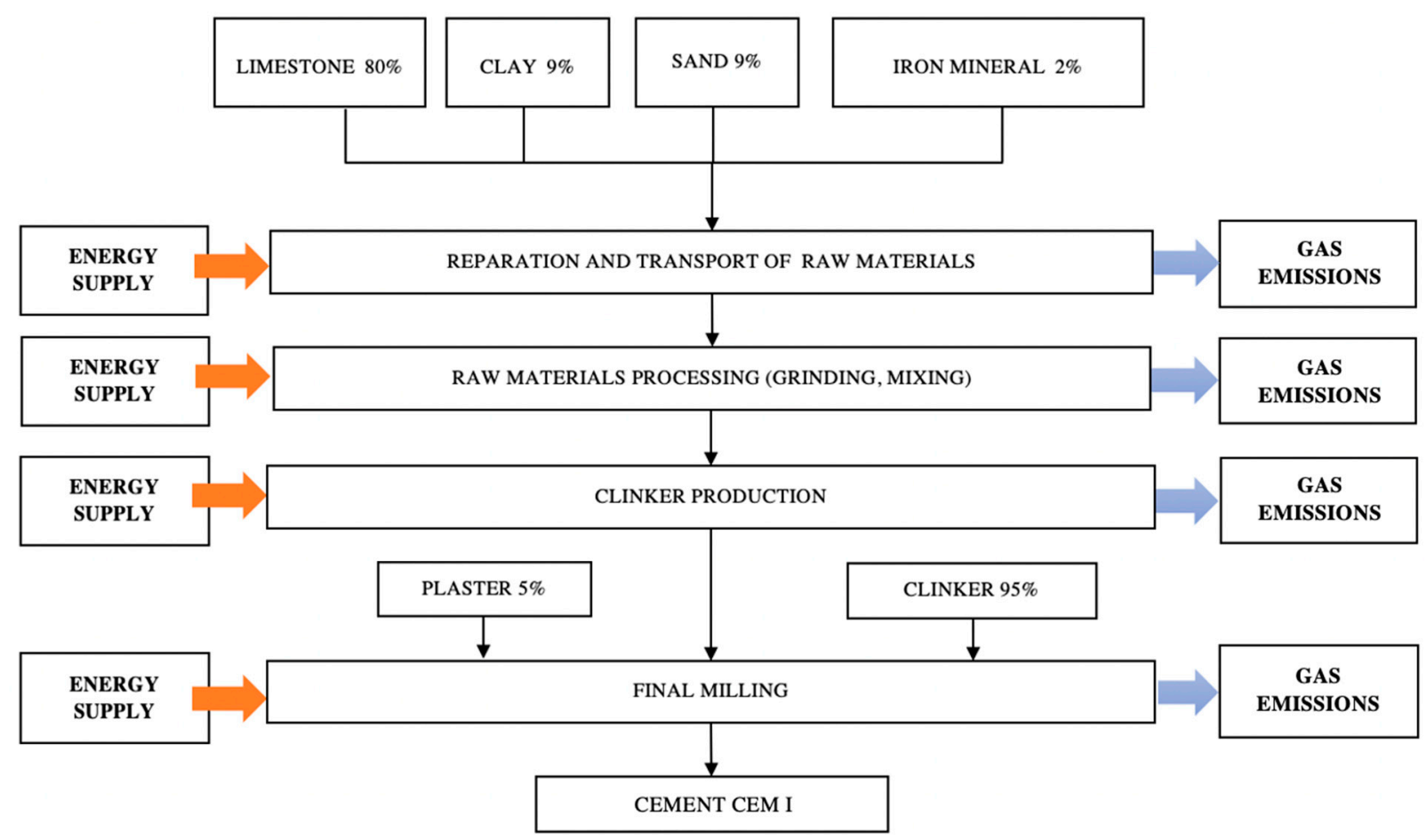

Figure 2. Basic process. Definition of the "cradle-to-gate" scope. System limits.

\subsubsection{Life Cycle Inventory Analysis and Impact Assessment}

LCA methodology requires definition of the environmental impact categories in cement production, which are GWP and primary energy demand. The former is quantified as $\mathrm{kg}$ of equivalent $\mathrm{CO}_{2}$, using the global protocol for Community-scale GHG emissions (GPC) of the international plant protection convention (IPPC) [59], while the latter is expressed as cumulative energy demand (CED) in MJ-equivalents. The CED of a product represents the direct and indirect energy consumption over its life cycle, including the energy consumed during the extraction, manufacturing, and removal of raw and auxiliary materials [60]. It has been reported that the main environmental burden of concrete production and the highest GHG emissions over its life cycle result from the manufacture of cement [61]. It has been proposed that the combined utilization of waste fuels and cements with additives alongside technological improvements in energy efficiency could reduce GHG emissions from cement manufacturing by $11 \%[6,62]$. The addition of limestone to Portland cement (during concrete production) has been estimated to reduce GHG emissions by $4 \%$ [63]. On the other hand, it has been found that improvements in transportation and the end-of-life of processes have relatively little impact on global GHG emissions from cement and concrete manufacturing, reducing them by less than $2 \%$ [64].

Emissions to the atmosphere of the clinker production system largely depend on the system design and on the nature and composition of the raw materials and fuels [65]. The base scheme of this research was the synthesis of processes performed in the reference cement factory (Figure 2), which uses a dry process. Based on the contribution of inputs and emissions, we obtained four stages: supply and preparation of raw materials; mixing and homogenization; clinkering; and grinding and mixing of clinker and additive.

The study hypothesis was that negative environmental impacts will be reduced when larger amounts of marble waste powder sludge are used to replace limestone in the production of raw cement and as a replacement for cement clinker. As observed in Table 2, the composition of the mixture follows Spanish norms for the reception of cement (RC-16) [66]. The percentage of plaster, used as setting retardant, remains constant and 
within the limit established by the EN $197-1$ norm for sulfate $\left(\mathrm{SO}_{3}\right)$ content $(<3.5 \%$ of the final cement weight).

The primary data on energy consumption and GHG emissions during marble cutting and cement transportation and manufacturing were complemented with average data from Europe in the Ecoinvent V3.7, Industry data library v.2017, Agri-footprint v5.0, US Life Cycle Inventory Database v2021, European and Danish Input/Output database, Environmental Footprint (EF.v2.0) and EXIOBASE v3.3 databases, using the commercial software SimaPro LCA version 9.1.1 (PRé Sustainability, Amersfoort, Netherlands), one of the most widely accepted methodologies in Europe [67].

The impacts were assessed by SimaPro version 9.1.1 software using the ReCiPe2016 method, since it provides harmonized implementation of the cause-and-effect pathways for the calculation of the characterization factors of the midpoint and the end point. This methodology is framed in the European level and is considered as the successor of previous methodologies (CML2001 and ECO-Indicator99). It integrates the approach oriented to the environmental problem and the approach oriented to the damage.

Life Cycle Impact Assessment (LCIA) translates emissions and resource extractions into a limited number of environmental impact results through the characterization factors. Each substance, resource and extraction belonging to the manufacturing process was classified and accounted for according to its group of resources, air, and soil compartments. Those groups are the emissions that contribute to the levels of toxicity of the manufacturing process. Its classification is based on the ISO 14,044 operational guide of the LCA manual and the SimaPro software was used for accounting.

The values of characterization factors for each issued substance are listed in the ACV manual: Operational Annex [68]. The calculations to perform the characterization, that is, to obtain the environmental impacts, were calculated with the SimaPro software.

Table 2. Study of cases as a function of the common cement classification of the norm for the reception of cements (RC-16) and the contribution of marble waste powder.

\begin{tabular}{cccc}
\hline \multirow{2}{*}{ Materials } & \multicolumn{3}{c}{ Type of Cement (RC-16) } \\
\cline { 2 - 4 } Clinker & CEM I & CEM II/A-LL & CEM II/B-LL \\
Plaster & $95-100 \%$ & $80-94 \%$ & $65-79 \%$ \\
Limestone & $<5 \%$ & $<5 \%$ & $<5 \%$ \\
\hline Materials & - & $<20 \%$ & $<35 \%$ \\
\cline { 2 - 4 } & CEM I & CEM II $/ \mathrm{A}-\mathrm{LL} *$ & $\mathrm{CEM} \mathrm{II/B-LL} \mathrm{*}$ \\
Clinker & $95-100 \%$ & $80-94 \%$ & $65-79 \%$ \\
Plaster & $<5 \%$ & $<5 \%$ & $<5 \%$ \\
Carbonated sludge & $80 \%$ of raw cement & $80 \%$ of raw $+<20 \%$ & $80 \%$ of raw $+<35 \%$ \\
\hline
\end{tabular}

* The asterisk sign was used to differentiate the derived eco-cements from the original class of cements.

\section{Results}

Among the scenarios examined in the LCA (Figure 3), the first is the total substitution of limestone by waste marble powder sludge to form raw cement that is then burned, yielding the Clinker* to produce cement CEM I* after the addition of plaster as retardant. This approach avoids the extraction of limestone from the quarry and its grinding, transportation, milling, and pre-homogenization. Given that the percentage $\mathrm{CaCO}_{3}$ is $98.52 \%$ for waste marble powder sludge versus $95 \%$ for limestone, a lower amount of waste is required to produce raw cement $(0.698 \mathrm{~kg} / \mathrm{kg}$ of waste vs. $0.705 \mathrm{~kg} / \mathrm{kg}$ of limestone), as shown in Table 3. In addition, the waste is dried outdoors and requires no electricity to reduce its humidity. Emissions from this material in cement production are therefore considered negligible and are not included in the system limits, only taking account of emissions from its processing and transportation.

As part of the scenario of total limestone substitution in raw cement to obtain clinker*, two maximum percentages of waste marble powder sludge were used, in accordance 
with technical norm RC-16 (options 2 and 3, Figure 3), reducing the amount of clinker* required. In alternative 2 , the waste is added with clinker* and plaster in the final milling phase, obtaining CEM II/A-LL* with a maximum addition of $20 \%$ waste and proportional reduction in clinker*. The letter $\mathrm{A}$ is included in this designation because the percentage addition is $\leq 20 \%$, and LL because the total organic carbon content in the waste marble powder sludge is $<0.2 \%$.

LCA alternative 3, using the percentages permitted by EN 197-1, includes the highest percentage of waste marble powder sludge and should therefore deliver the greatest reduction in environmental impact. Limestone is replaced by the waste in the formation of raw cement and the production of clinker*, which is milled to produce cement CEM II/B-LL ${ }^{*}$, containing $<65 \%$ clinker with plaster and $35 \%$ waste.

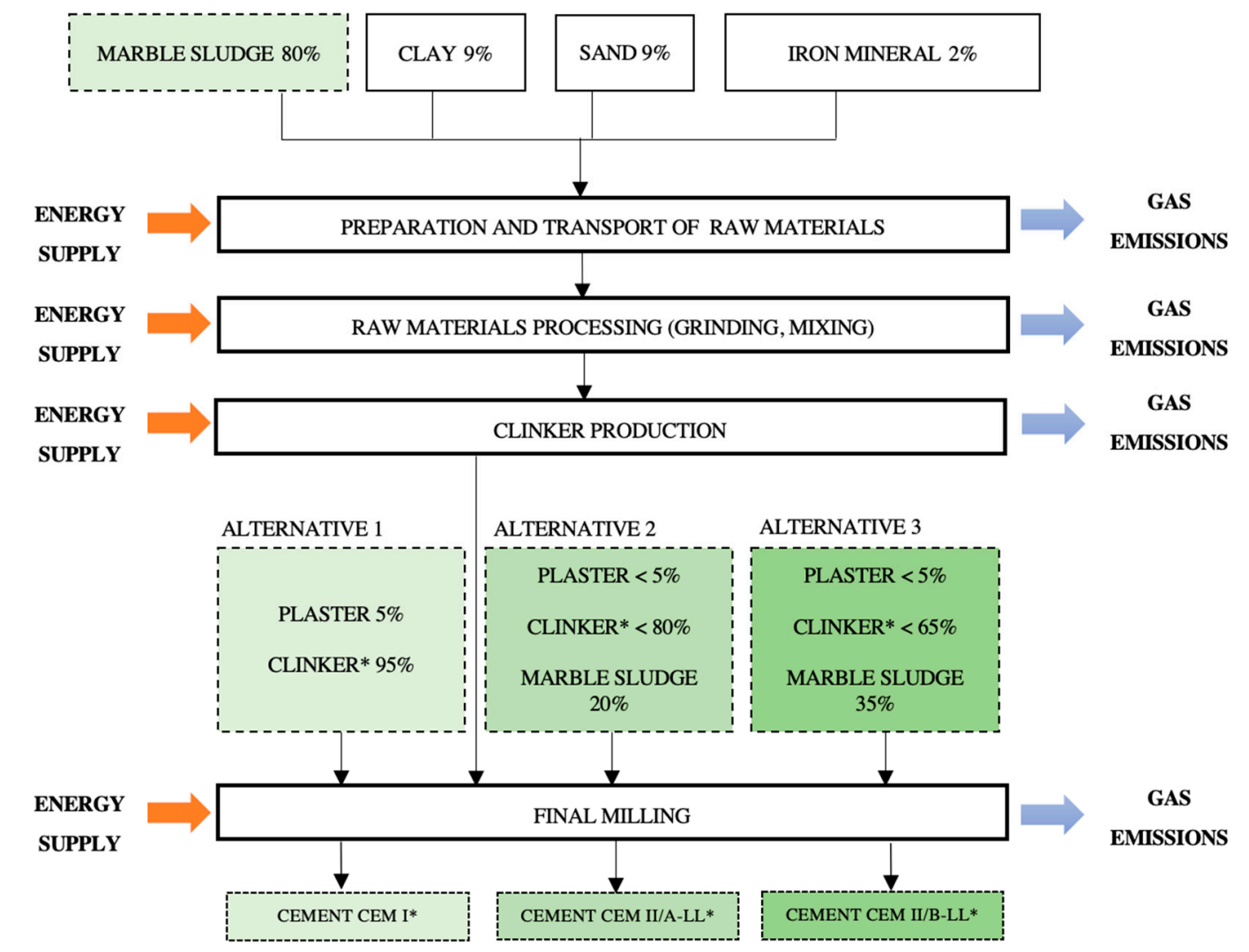

Figure 3. Process with limestone substitution in raw cement; process with limestone substitution in raw clinker with $20 \%$ additives; and process with limestone substitution in raw clinker with $35 \%$ additives. ${ }^{*}$ The asterisk sign was used to differentiate the derived eco-cements from the original class of cements.

The inventory (Table 3) was based on data provided by the factory and complemented by the Ecoinvent database and published corrections [28]. High-quality data are essential for the evaluation of environmental performance, especially for comparative ratings [69].

Table 3 shows that the marble waste sludge has a higher purity $\left(\mathrm{CaCO}_{3}\right.$ content of $98.52 \%$ vs. $95.00 \%$ ), indicating that a smaller amount is required to substitute limestone, although its $\mathrm{CO}_{2}$ emissions are slightly higher $(0.008 \mathrm{~kg} / \mathrm{kg})$. One advantage of using marble waste sludge is that it does not require grinding, and its mixture with clinker requires much less energy to prepare raw cement, with $75 \%$ less energy being used in the milling process $(0.012 \mathrm{kWh} / \mathrm{kg}$ vs. $0.048 \mathrm{kWh} / \mathrm{kg})$. Finally, total material transportation costs are lower when limestone is replaced with waste sludge, which is taken to the factory by truck, with no transportation by boat. 
Table 3. Basic inventory and process with limestone substitution and 35\% additives.

\begin{tabular}{|c|c|c|c|}
\hline Component & Basic Process & $\begin{array}{c}\text { Limestone Substitution and } \\
35 \% \text { Additives }\end{array}$ & Data Source \\
\hline & Clinker & Clinker * & \\
\hline Coal & $4.90 \times 10^{-2} \mathrm{~kg} / \mathrm{kg}$ & $4.90 \times 10^{-2} \mathrm{~kg} / \mathrm{kg}$ & Factory \\
\hline Petroleum coke & $6.50 \times 10^{-2} \mathrm{~kg} / \mathrm{kg}$ & $6.50 \times 10^{-2} \mathrm{~kg} / \mathrm{kg}$ & Factory \\
\hline Fuel oil & $0.0122 \mathrm{~kg} / \mathrm{kg}$ & $0.0122 \mathrm{~kg} / \mathrm{kg}$ & Factory \\
\hline Diesel & $0.001 \mathrm{~kg} / \mathrm{kg}$ & $0.001 \mathrm{~kg} / \mathrm{kg}$ & Factory \\
\hline Natural gas & $1.06 \times 10^{-4} \mathrm{MJ} / \mathrm{kg}$ & $1.06 \times 10^{-4} \mathrm{MJ} / \mathrm{kg}$ & Factory \\
\hline $\mathrm{CO}_{2}$ from fuels & $0.390 \mathrm{~kg} / \mathrm{kg}$ & $0.390 \mathrm{~kg} / \mathrm{kg}$ & Ecoinvent \\
\hline $\mathrm{CO}_{2}$ from limestone & $0.295 \mathrm{~kg} / \mathrm{kg}$ & $0.303 \mathrm{~kg} / \mathrm{kg}$ & Ecoinvent \\
\hline Slag & $0.213 \mathrm{~kg} / \mathrm{kg}$ & $0.218 \mathrm{~kg} / \mathrm{kg}$ & Factory \\
\hline Sandstone & $0.071 \mathrm{~kg} / \mathrm{kg}$ & $0.072 \mathrm{~kg} / \mathrm{kg}$ & Factory \\
\hline Lamellae & $0.012 \mathrm{~kg} / \mathrm{kg}$ & $0.012 \mathrm{~kg} / \mathrm{kg}$ & Factory \\
\hline Limestone/Marble waste sludge powder & $0.705 \mathrm{~kg} / \mathrm{kg}$ & $0.698 \mathrm{~kg} / \mathrm{kg}$ & Factory \\
\hline EE in clinker & $0.0476 \mathrm{KWh} / \mathrm{kg}$ & $0.0476 \mathrm{KWh} / \mathrm{kg}$ & Ecoinvent \\
\hline EE in raw cement milling & $0.048 \mathrm{KWh} / \mathrm{kg}$ & $0.012 \mathrm{KWh} / \mathrm{kg}$ & Ecoinvent \\
\hline Process water & $0.00059 \mathrm{~m}^{3} / \mathrm{kg}$ & $0.00059 \mathrm{~m}^{3} / \mathrm{kg}$ & Factory \\
\hline Drinking water & 0.000447 ton $/ \mathrm{kg}$ & $0.000447 \mathrm{ton} / \mathrm{kg}$ & Factory \\
\hline Transport by truck & $0.188 \mathrm{tkm} / \mathrm{kg}$ & $0.224 \mathrm{tkm} / \mathrm{kg}$ & Ecoinvent \\
\hline Transport by boat & $0.17 \mathrm{tkm} / \mathrm{kg}$ & - & Ecoinvent \\
\hline CEMENT & CEM I & CEM II/B-LL * & \\
\hline Transport by truck & $0.0606 \mathrm{tkm} / \mathrm{kg}$ & $0.1225 \mathrm{tkm} / \mathrm{kg}$ & Ecoinvent \\
\hline Total clinker consumed & $0.950 \mathrm{~kg} / \mathrm{kg}$ & $0.603 \mathrm{~kg} / \mathrm{kg}$ & Factory \\
\hline Plaster & $0.050 \mathrm{~kg} / \mathrm{kg}$ & $0.041 \mathrm{~kg} / \mathrm{kg}$ & Factory \\
\hline Marble waste sludge powder & $0 \mathrm{~kg} / \mathrm{kg}$ & $0.355 \mathrm{~kg} / \mathrm{kg}$ & - \\
\hline Electrical energy & $0.052 \mathrm{KWh} / \mathrm{kg}$ & $0.0338 \mathrm{KWh} / \mathrm{kg}$ & Ecoinvent \\
\hline
\end{tabular}

$\mathrm{EE}=$ Electrical energy. ${ }^{*}$ The asterisk sign was used to differentiate the derived eco-cements from the original class of cements.

The most relevant factor explaining the more favorable environmental impact of preparing eco-cement CEM II/B-LL* is the lesser amount of clinker consumed when marble waste sludge is added. Given that CEM I is an additive-free cement, the truck transportation it requires is half that needed for CEM II/B-LL*.

After carrying out the inventory, an LCIA was performed, assigning inventory inputs and outputs to the different impact categories. Based on the characterization factors, indicators were obtained for the conventional process and for the process using $35 \%$ additives with total limestone substitution, as the environmental strategy with greatest impact (Table 4).

Table 4. Results of LCIA indicators, conventional process, and process with limestone substitution and 35\% additives.

\begin{tabular}{ccccc}
\hline Substance & Section & Unit & Normal Process & $\begin{array}{c}\text { Process with Limestone } \\
\text { Substitution and 35\% Additives }\end{array}$ \\
\hline Coal, brown, in soil & Raw & $\mathrm{kg}$ & $2.6018 \times 10^{-2}$ & $1.4320 \times 10^{-2}$ \\
Coal, hard, not specified, in soil & Raw & $\mathrm{kg}$ & $8.1269 \times 10^{-2}$ & $5.0780 \times 10^{-2}$ \\
Gas, natural, in soil & Raw & $\mathrm{m}^{3}$ & $1.6506 \times 10^{-2}$ & $1.0564 \times 10^{-2}$ \\
Oil, crude, in soil & Raw & $\mathrm{kg}$ & $1.1691 \times 10^{-1}$ & $8.1591 \times 10^{-2}$ \\
Water, cooling, natural origin not & Raw & $\mathrm{m}^{3}$ & $3.1323 \times 10^{-3}$ & $1.8084 \times 10^{-3}$ \\
specified/m m $^{3}$ & & & & $4.5948 \times 10^{-1}$ \\
Water, turbine use, natural origin not & Raw & $\mathrm{m}^{3}$ & & $5.5511 \times 10^{-1}$ \\
specified & Air & $\mathrm{kg}$ & $8.4230 \times 10^{-1}$ & $4.4983 \times 10^{-6}$ \\
Carbon dioxide, fossil & Air & $\mathrm{kg}$ & $7.0630 \times 10^{-6}$ & $3.2678 \times 10^{-4}$ \\
Dinitrogen monoxide & Air & $\mathrm{kg}$ & $4.7811 \times 10^{-4}$ & $5.6462 \times 10^{-1}$ \\
Methane, fossil & Air & $\mathrm{kg}$ & $8.5636 \times 10^{-1}$ & $1.2070 \times 10^{-3}$ \\
$\quad$ GHG & Air & $\mathrm{kg}$ & $1.5937 \times 10^{-3}$ & \\
Nitrogen oxide & &
\end{tabular}


Table 4. Cont.

\begin{tabular}{ccccc}
\hline Substance & Section & Unit & Normal Process & $\begin{array}{c}\text { Process with Limestone } \\
\text { Substitution and 35\% Additives }\end{array}$ \\
\hline NMVOC & Air & $\mathrm{kg}$ & $2.9612 \times 10^{-4}$ & $2.2172 \times 10^{-4}$ \\
Particles, $<2.5 \mathrm{um}$ & Air & $\mathrm{kg}$ & $8.9508 \times 10^{-5}$ & $6.1561 \times 10^{-5}$ \\
Particles, $>10 \mathrm{um}$ & Air & $\mathrm{kg}$ & $3.5062 \times 10^{-4}$ & $1.8458 \times 10^{-4}$ \\
Particles, $>2.5$ um and $<10 \mathrm{um}$ & Air & $\mathrm{kg}$ & $1.0298 \times 10^{-4}$ & $5.4322 \times 10^{-5}$ \\
Sulfur dioxide & Air & $\mathrm{kg}$ & $3.3898 \times 10^{-3}$ & $2.1530 \times 10^{-3}$ \\
BOD5, biological oxygen demand & Water & $\mathrm{kg}$ & $1.3404 \times 10^{-3}$ & $9.0632 \times 10^{-4}$ \\
COD, chemical oxygen demand & Water & $\mathrm{kg}$ & $1.5508 \times 10^{-3}$ & $1.1052 \times 10^{-3}$ \\
DOC, dissolved organic carbon & Water & $\mathrm{kg}$ & $4.2541 \times 10^{-4}$ & $2.8977 \times 10^{-4}$ \\
Nitrate & Water & $\mathrm{kg}$ & $2.5444 \times 10^{-6}$ & $1.7342 \times 10^{-6}$ \\
PAH (Polycyclic Aromatic Hydrocarbons) & Water & $\mathrm{kg}$ & $3.9898 \times 10^{-8}$ & $2.7401 \times 10^{-8}$ \\
Phosphate & Water & $\mathrm{kg}$ & $5.2351 \times 10^{-6}$ & $3.9545 \times 10^{-6}$ \\
Sulfate & Water & $\mathrm{kg}$ & $4.9035 \times 10^{-4}$ & $2.8335 \times 10^{-4}$ \\
Arsenic & Water & $\mathrm{kg}$ & $4.2604 \times 10^{-4}$ & $2.9025 \times 10^{-4}$ \\
Cadmium & Soil & $\mathrm{kg}$ & $1.2491 \times 10^{-9}$ & $8.4610 \times 10^{-10}$ \\
Chromium VI & Soil & $\mathrm{kg}$ & $1.6440 \times 10^{-10}$ & $1.6072 \times 10^{-10}$ \\
Mercury & Soil & $\mathrm{kg}$ & $3.8321 \times 10^{-8}$ & $2.1789 \times 10^{-8}$ \\
Nickel & Soil & $\mathrm{kg}$ & $1.1348 \times 10^{-12}$ & $8.2473 \times 10^{-13}$ \\
Vanadium & Soil & $\mathrm{kg}$ & $1.5667 \times 10^{-9}$ & $1.7566 \times 10^{-9}$ \\
Zinc & Soil & $\mathrm{kg}$ & $1.5897 \times 10^{-10}$ & $8.5736 \times 10^{-11}$ \\
& Soil & $\mathrm{kg}$ & $3.3479 \times 10^{-7}$ & $3.8050 \times 10^{-7}$ \\
\hline
\end{tabular}

The final LCA phase is the interpretation of LCIA results, highlighting the values of the most relevant substances (Figure 4). All of these values are lower in the eco-cement proposal than in conventional production because of the action taken on limestone and clinker contents. Given that limestone is a primary element in cement production, it has a higher limestone $\mathrm{kg} /$ clinker $\mathrm{kg}$ ratio than the products that comprise it. In the case of clinker, reducing the amount necessary to produce $1 \mathrm{~kg}$ of cement directly and proportionally yields a reduction in supplies and emissions.

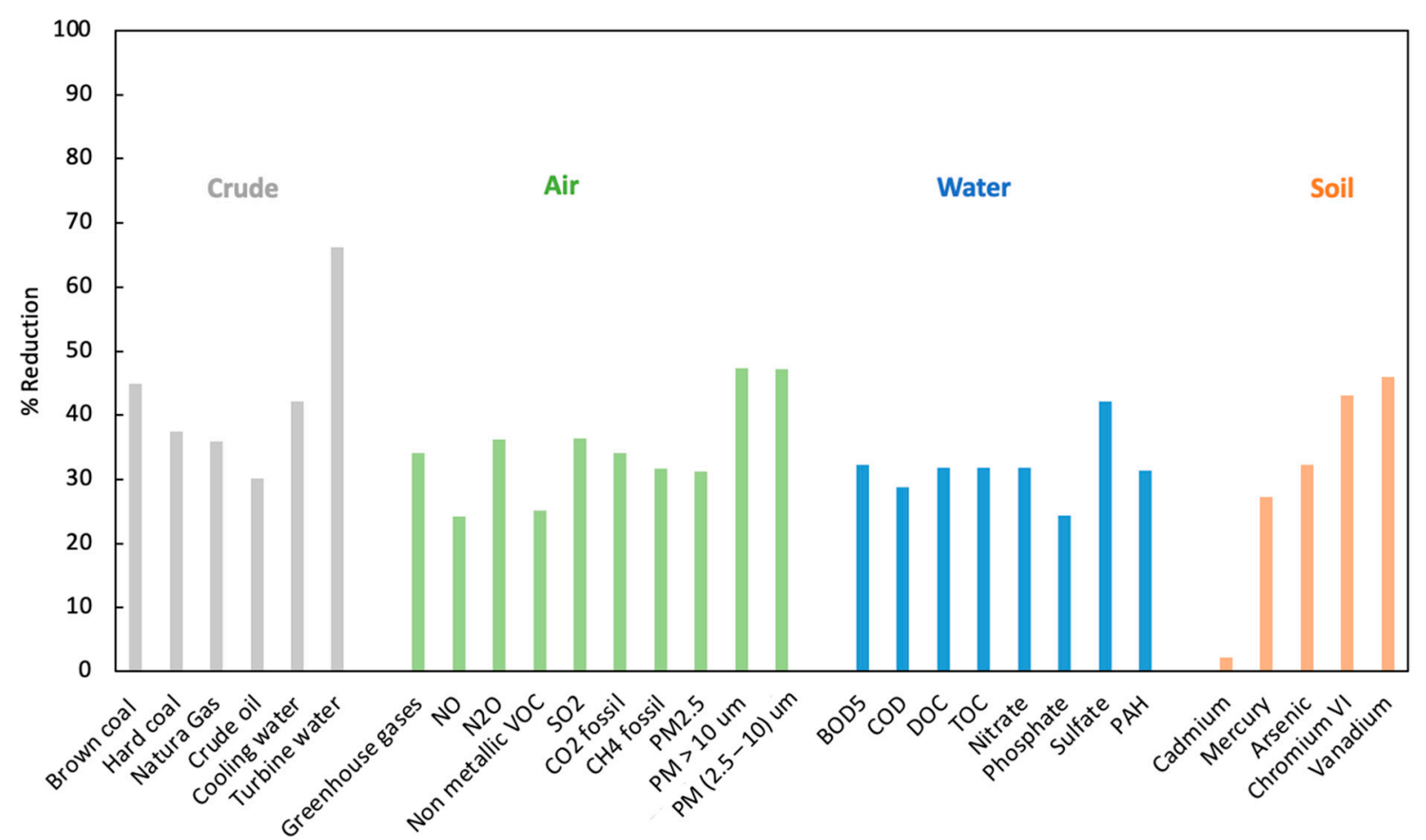

Figure 4. Chart showing lower LCIA indicators for the process with limestone substitution and 35\% additives (alternative 3) than for the basic process. 
Importantly, the LCIA reveals that GHG levels are around 34\% lower for the production of CEM II/B-LL* versus CEM I cement. In addition, $60 \%$ less water is used for turbines and a lower amount of particles is emitted into the air. Future LCA studies of eco-cement or "green concrete" should address specific functional concrete measures and exposure conditions expected [70]. Likewise, an aspect of increasing scientific interest in LCA analyses is the need to model rebound or recovery effects [71], given that the environmental impact of efficiency measures is not necessarily in the same direction, sometimes producing indirect effects that are not always positive.

\section{Conclusions}

This study uses LCA methodology to present an example of sustainability improvement in industry. It was applied to evaluate a reduction in the environmental impact of cement production. The results allow a priori assessment by industries of the effects of adding marble powder in cement production.

All LCIA indicators are lower for the proposed eco-cement than for conventionally produced cement. The actions on limestone and clinker, two key elements in cement production, directly and proportionally reduce inputs and emissions.

GHG emissions are around 34\% lower with the production of CEM II/B-LL* cement than with the production of CEM I cement.

The replacement of limestone with marble powder sludge in raw cement avoids three stages in the production process: extraction, transportation from the quarry, and roll milling. The addition of marble sludge to clinker in cement production avoids ball milling, reducing GHG emissions and energy consumption. The higher percentage addition of sledge, the less clinker is required, which also reduces the GHG emitted in the clinkering process.

The system limits considered in this study covers the extraction of raw materials, preparation and production of cement and transportation. However, industrial machinery and equipment might be considered for a more in detailed future LCA analysis, even though they are involved and shared with other industrial processes. An analysis of LCA for eco-cement production is given, considering Spanish regional set-up following national and European standards and norms. Nevertheless, it could be generalized and extended to other similar processes adopting their constrains, specifications, and regulations.

It is worth mentioning that, for example, one of the strategies in the present study is to replace $6-35 \%$ of the limestone with marble waste powder in "green" cements, obtaining a product that meets European Norm EN 197-1:2011. It is not a question of merely presenting an option but rather evaluating the technological validity of its real-world application in the market, given that the scientific literature has long addressed the possibility of using limestone additives for cement and concrete.

It would be also interesting to analyze model rebounds or recovery effects given that the environmental impact of efficiency measures is not necessarily in the same direction, sometimes producing indirect effects that are not always positive. In addition, Future LCA studies of eco-cement or "green concrete" should address specific functional concrete measures and exposure conditions expected.

Supplementary Materials: The following are available online at https://www.mdpi.com/article/10 .3390 /ijerph182010968/s1, Figure S1: Cement production worldwide. Source: Statica $\odot$, Figure S2: Documents published for the study keywords during the period 1994-2020 in the Scopus@ bibliographic database, Figure S3: Graphic representation of the distribution of documents with the key words of interest by thematic area during the period 1994-2020 in the Scopus@ database, Table S1: Classification of common cements. Obtained from the Instruction of the Reception of Cements (RC-16).

Author Contributions: Conceptualization, A.R.S., M.S.P. and J.R.U.; methodology, A.R.S. and M.S.P.; software, V.C.R. and M.V.L.R.; validation, J.R.U., M.S.P. and A.R.S.; formal analysis, A.R.S., V.C.R. and M.V.L.R.; investigation, V.C.R., A.R.S. and M.S.P.; resources, J.R.U., M.S.P. and M.V.L.R.; data curation, V.C.R., A.R.S., M.S.P. and M.V.L.R.; writing—original draft preparation, V.C.R., A.R.S. and M.S.P.; writing-review and editing, V.C.R., A.R.S., M.S.P., M.V.L.R. and J.R.U.; visualization, M.V.L.R., 
A.R.S. and J.R.U.; supervision, M.S.P., J.R.U. and A.R.S.; project administration, M.S.P. and J.R.U.; funding acquisition, M.S.P. and J.R.U. All authors have read and agreed to the published version of the manuscript.

Funding: This research was funded by Junta de Andalucía and Fondo Europeo de Desarrollo Regional (FEDER) Ref. P18-RT-4193.

Institutional Review Board Statement: Not applicable.

Informed Consent Statement: Not applicable.

Acknowledgments: The authors acknowledge the support given by the Research Project "Nanomateriales funcionalizados para su aplicación en procesos de desalación y depuración de aguas, Ref. P18-RT-4193" and Richard Davies for the manuscript's English corrections.

Conflicts of Interest: The authors declare no conflict of interest.

\section{References}

1. US Geological Survey. Cement Production Globally and in the U.S. from 2010 to 2019 (in Million Metric Tons) [Graph]. In Statista. Available online: https://www.statista.com/statistics/219343/cement-production-worldwide/ (accessed on 12 July 2021).

2. International Energy Agency. Low-Carbon Transition in the Cement Industry: Technology Roadmap. Available online: https: //www.iea.org/reports/technology-roadmap-low-carbon-transition-in-the-cement-industry (accessed on 12 July 2021).

3. Worrell, E.; Price, L.; Martin, N.; Hendriks, C.; Meida, L.O. Carbon Dioxide Emissions from the Global Cement Industry. Annu. Rev. Energy Environ. 2001, 26, 303-329. [CrossRef]

4. Lehne, J.; Preston, F. Making Concrete Change: Innovation in Low-Carbon Cement and Concrete; Chatham House-The Royal Institute of International Affairs: London, UK, 2018.

5. Andrew, R.M. Global $\mathrm{CO}_{2}$ Emissions from Cement Production, 1928-2018. Earth Syst. Sci. Data 2019, 11, 1675-1710. [CrossRef]

6. Huntzinger, D.N.; Eatmon, T. A life-cycle assessment of Portland cement manufacturing: Comparing the traditional process with alternative technologies. J. Clean. Prod. 2009, 17, 668-675. [CrossRef]

7. Chen, C.; Habert, G.; Bouzidi, Y.; Jullien, A. Environmental impact of cement production: Detail of the different processes and cement plant variability evaluation. J. Clean. Prod. 2010, 18, 478-485. [CrossRef]

8. Puertas, F.; García-Díaz, I.; Barba-Juan, A.; Gazulla, M.; Palacios, M.; Gómez-Tena, M.P.; Martinez-Ramirez, S. Ceramic wastes as alternative raw materials for Portland cement clinker production. Cem. Concr. Compos. 2008, 30, 798-805. [CrossRef]

9. Kim, S.-H.; Hwang, J.-P. The $\mathrm{CO}_{2}$ Emission in the Process of Cement Manufacture Depending on CaO Content. J. Korea Concr. Inst. 2013, 25, 365-370. [CrossRef]

10. Cement Sustainability Initiative. Global Cement Data Base on $\mathrm{CO}_{2}$ and Energy Information, GNR. Getting the Numbers Right Database, Gross $\mathrm{CO}_{2}$ Emissions. Ratios: Weighted Average, World 21\% Coverage in 2018. Available online: https: / / cutt.ly / bh59mBK (accessed on 24 December 2020).

11. Cement Sustainability Initiative. CSI Global Cement Data Base on $\mathrm{CO}_{2}$ and Energy Information, GNR. Getting the Numbers Right Database, Gross $\mathrm{CO}_{2}$ Emissions. Ratios: Weighted Average, Spain 63\% Coverage in 2018. Available online: https:// cutt.ly/th59b7i (accessed on 24 December 2020).

12. Schneider, M. The cement industry on the way to a low-carbon future. Cem. Concr. Res. 2019, 124, 105792. [CrossRef]

13. European Commission. Paris Agreement. Available online: https:/ / cutt.ly/Ch59gtV (accessed on 22 December 2020).

14. Aruntaş, H.Y.; Gürü, M.; Dayi, M.; Tekin, I. Utilization of waste marble dust as an additive in cement production. Mater. Des. 2010, 31, 4039-4042. [CrossRef]

15. Bignozzi, M. The Use of Industrial Waste for the Production of New Blended Cement. In Waste Management: Research Advances to Convert Waste to Wealth; Nova Science Publishers, Inc.: Hauppauge, NY, USA, 2010.

16. Kavas, T.; Olgun, A. Properties of Cement and Mortar Incorporating Marble Dust and Crushed Brick. Ceram. Silik. 2008, 52, 24.

17. Yen, C.-L.; Tseng, D.-H.; Lin, T.-T. Characterization of eco-cement paste produced from waste sludges. Chemosphere 2011, 84, 220-226. [CrossRef]

18. Baeza, F.; Payá, J.; Galao, O.; Saval, J.; Garcés, P. Blending of industrial waste from different sources as partial substitution of Portland cement in pastes and mortars. Constr. Build. Mater. 2014, 66, 645-653. [CrossRef]

19. Prusty, J.K.; Patro, S.K.; Basarkar, S. Concrete using agro-waste as fine aggregate for sustainable built environment-A review. Int. J. Sustain. Built Environ. 2016, 5, 312-333. [CrossRef]

20. Grilo, M.J.; Pereira, J.; Costa, C. Waste Marble Dust Blended Cement. Mater. Sci. Forum 2012, 730-732, 671-676. [CrossRef]

21. Ashish, D.K. Concrete made with waste marble powder and supplementary cementitious material for sustainable development. J. Clean. Prod. 2019, 211, 716-729. [CrossRef]

22. Singh, M.; Srivastava, A.; Bhunia, D. Long term strength and durability parameters of hardened concrete on partially replacing cement by dried waste marble powder slurry. Constr. Build. Mater. 2019, 198, 553-569. [CrossRef]

23. de Brito, J.; Kurda, R. The past and future of sustainable concrete: A critical review and new strategies on cement-based materials. J. Clean. Prod. 2021, 281, 123558. [CrossRef] 
24. Chen, J.; Kwan, A.; Jiang, Y. Adding limestone fines as cement paste replacement to reduce water permeability and sorptivity of concrete. Constr. Build. Mater. 2014, 56, 87-93. [CrossRef]

25. Perera, A.G.; Dionisio, M.D.P.S.; Sancha, P. Alternativas de reducción de las emisiones de dióxido de carbono (C02) en la producción de cemento. Propuesta de un modelo de evaluación. Innovar 2016, 26, 51-66. [CrossRef]

26. European Commission. European Platform on Life Cycle Assessment (LCA). Available online: https://cutt.ly/6h59vTl (accessed on 25 December 2020).

27. Gursel, A.P.; Masanet, E.; Horvath, A.; Stadel, A. Life-cycle inventory analysis of concrete production: A critical review. Cem. Concr. Compos. 2014, 51, 38-48. [CrossRef]

28. Aguado, A.; Josa, A.; Cardim, A. Strengths and Weaknesses of Life Cycle Inventories (LCI) of Cement for Its Use in Life Assesments (LCA). In Boletin de la Sociedad Espanola de Ceramica y Vidrio; Sociedad Espanola de Ceramica y Vidrio: Madrid, Spain, 2004; Volume 43, pp. 587-590. [CrossRef]

29. European Commission; Joint Research Centre; Institute for Environment and Sustainability. International Reference Life Cycle Data System (ILCD) Handbook General Guide for Life Cycle Assessment: Provisions and Action Steps; Publications Office of the European Union: Luxembourg, 2011.

30. Tam, V.W.; Li, J.; Cai, H. System dynamic modeling on construction waste management in Shenzhen, China. Waste Manag. Res. 2014, 32, 441-453. [CrossRef] [PubMed]

31. Ding, Z.; Wang, Y.; Zou, P. An agent based environmental impact assessment of building demolition waste management: Conventional versus green management. J. Clean. Prod. 2016, 133, 1136-1153. [CrossRef]

32. Yuan, H. A model for evaluating the social performance of construction waste management. Waste Manag. 2012, 32, 1218-1228. [CrossRef]

33. An, J.; Middleton, R.S.; Li, Y. Environmental Performance Analysis of Cement Production with $\mathrm{CO}_{2}$ Capture and Storage Technology in a Life-Cycle Perspective. Sustainability 2019, 11, 2626. [CrossRef]

34. Wu, H.; Zuo, J.; Yuan, H.; Zillante, G.; Wang, J. A review of performance assessment methods for construction and demolition waste management. Resour. Conserv. Recycl. 2019, 150, 104407. [CrossRef]

35. Nicoara, A.I.; Grumezescu, A.M.; Vrabec, M.; Šmuc, N.R.; Šturm, S.; Ow-Yang, C.; Gulgun, M.A.; Bundur, Z.B.; Ciuca, I.; Vasile, B.S. End-of-Life Materials Used as Supplementary Cementitious Materials in the Concrete Industry. Materials 2020, 13, 1954. [CrossRef] [PubMed]

36. Scrivener, K.L.; John, V.M.; Gartner, E.M. Eco-efficient cements: Potential economically viable solutions for a low-CO 2 cementbased materials industry. Cem. Concr. Res. 2018, 114, 2-26. [CrossRef]

37. García-Gusano, D.; Garraín, D.; Herrera, I.; Cabal, H.; Lechón, Y. Life Cycle Assessment of applying $\mathrm{CO}_{2}$ post-combustion capture to the Spanish cement production. J. Clean. Prod. 2015, 104, 328-338. [CrossRef]

38. Kwon, E.; Ahn, J.; Cho, B.; Park, D. A study on development of recycled cement made from waste cementitious powder. Constr. Build. Mater. 2015, 83, 174-180. [CrossRef]

39. Li, C.; Cui, S.; Nie, Z.; Gong, X.; Wang, Z.; Itsubo, N. The LCA of portland cement production in China. Int. J. Life Cycle Assess. 2015, 20, 117-127. [CrossRef]

40. Yang, K.-H.; Jung, Y.-B.; Cho, M.-S.; Tae, S.-H. Effect of supplementary cementitious materials on reduction of $\mathrm{CO}_{2}$ emissions from concrete. J. Clean. Prod. 2015, 103, 774-783. [CrossRef]

41. Tait, M.W.; Cheung, W.M. A comparative cradle-to-gate life cycle assessment of three concrete mix designs. Int. J. Life Cycle Assess. 2016, 21, 847-860. [CrossRef]

42. Esmaeilkhanian, B.; Khayat, K.; Wallevik, O.H. Mix design approach for low-powder self-consolidating concrete: Eco-SCCContent optimization and performance. Mater. Struct. 2017, 50, 124. [CrossRef]

43. Hossain, U.; Poon, C.S.; Lo, I.M.C.; Cheng, J.C. Comparative LCA on using waste materials in the cement industry: A Hong Kong case study. Resour. Conserv. Recycl. 2017, 120, 199-208. [CrossRef]

44. Di Maria, A.; Eyckmans, J.; van Acker, K. Downcycling versus recycling of construction and demolition waste: Combining LCA and LCC to support sustainable policy making. Waste Manag. 2018, 75, 3-21. [CrossRef] [PubMed]

45. Nakic, D. Environmental evaluation of concrete with sewage sludge ash based on LCA. Sustain. Prod. Consum. 2018, 16, 193-201. [CrossRef]

46. Medina, G.; del Bosque, I.S.; Frías, M.; de Rojas, M.S.; Medina, C. Energy performance and calorimetric behaviour of cements bearing granite sludge. Powder Technol. 2019, 356, 517-527. [CrossRef]

47. Akbar, A.; Liew, K. Assessing recycling potential of carbon fiber reinforced plastic waste in production of eco-efficient cementbased materials. J. Clean. Prod. 2020, 274, 123001. [CrossRef]

48. Ali, Z.S.; Hosseinpoor, M.; Yahia, A. New aggregate grading models for low-binder self-consolidating and semi-self-consolidating concrete (Eco-SCC and Eco-semi-SCC). Constr. Build. Mater. 2020, 265, 120314. [CrossRef]

49. Patel, D.; Shrivastava, R.; Tiwari, R.; Yadav, R. Properties of cement mortar in substitution with waste fine glass powder and environmental impact study. J. Build. Eng. 2020, 27, 100940. [CrossRef]

50. Mehdipour, S.; Nikbin, I.; Dezhampanah, S.; Mohebbi, R.; Moghadam, H.; Charkhtab, S.; Moradi, A. Mechanical properties, durability and environmental evaluation of rubberized concrete incorporating steel fiber and metakaolin at elevated temperatures. J. Clean. Prod. 2020, 254, 120126. [CrossRef] 
51. Zulcão, R.; Calmon, J.L.; Rebello, T.A.; Vieira, D.R. Life cycle assessment of the ornamental stone processing waste use in cement-based building materials. Constr. Build. Mater. 2020, 257, 119523. [CrossRef]

52. Chaid, R.; Rendell, F.; Jauberthie, R. Impact or Marble Powder Combined with Limestone CEM II on Concrete Durability. In Proceedings of the 13th Congress of the Chemistry of Cement, Madrid, Spain, 3-8 July 2011.

53. Kaliyavaradhan, S.K.; Ling, T.-C.; Mo, K.H. Valorization of waste powders from cement-concrete life cycle: A pathway to circular future. J. Clean. Prod. 2020, 268, 122358. [CrossRef]

54. Schneider, M.; Romer, M.; Tschudin, M.; Bolio, H. Sustainable cement production-Present and future. Cem. Concr. Res. 2011, 41, 642-650. [CrossRef]

55. Nisbet, M.; Vangeem, M.; Consultants, J.; van Geem, M.C. Environmental Life Cycle Inventory of Portland Cement and Concrete. Environmental Life Cycle Inventory; Portland Cement Association: Skokie, IL, USA, 2002.

56. International Organization for Standardization: ISO 14040. Environmental Management_Life Cycle Assessment-Principles and Framework; International Organization for Standardization: Geneva, Switzerland, 2006.

57. Flower, D.J.M.; Sanjayan, J.G. Green house gas emissions due to concrete manufacture. Int. J. Life Cycle Assess. 2007, 12, 282-288. [CrossRef]

58. Serres, N.; Braymand, S.; Feugeas, F. Environmental evaluation of concrete made from recycled concrete aggregate implementing life cycle assessment. J. Build. Eng. 2016, 5, 24-33. [CrossRef]

59. Griggs, D.J.; Noguer, M. Climate Change 2001: The Scientific Basis. Contribution of Working Group I to the Third Assessment Report of the Intergovernmental Panel on Climate Change. Weather 2002, 57, 267-269. [CrossRef]

60. Huijbregts, M.A.; Hellweg, S.; Frischknecht, R.; Hungerbühler, K.; Hendriks, A.J. Ecological footprint accounting in the life cycle assessment of products. Ecol. Econ. 2008, 64, 798-807. [CrossRef]

61. Collins, F. Inclusion of carbonation during the life cycle of built and recycled concrete: Influence on their carbon footprint. Int. J. Life Cycle Assess. 2010, 15, 549-556. [CrossRef]

62. Ortiz, O.; Castells, F.; Sonnemann, G. Sustainability in the construction industry: A review of recent developments based on LCA. Constr. Build. Mater. 2009, 23, 28-39. [CrossRef]

63. Masanet, E. Reducing California's Greenhouse Gas Emissions through Product Life-Cycle Optimization; Lawrence Berkeley National Laboratory: Berkeley, CA, USA, 2005.

64. Lippiatt, B.C.; Ahmad, S. Measuring the Life-Cycle Environmental and Economic Performance of Concrete: The Bees Approach; International Workshop on Sustainable Development and Concrete Technology: Beijing, China, 2004.

65. Gäbel, K.; Forsberg, P.; Tillman, A.-M. The design and building of a lifecycle-based process model for simulating environmental performance, product performance and cost in cement manufacturing. J. Clean. Prod. 2004, 12, 77-93. [CrossRef]

66. de la Presidencia, M. Real Decreto 256/2016, de 10 de Junio, Por El Que Se Aprueba La Instrucción Para La Recepción de Cementos RC-16; Agencia Estatal Boletín Oficial del Estado: Madrid, Spain, 2016; Volume 153, pp. 45755-45824.

67. Goedkoop, M.J.; Oele, M.; de Schrywer, A.; Vieira, M. SimaPro Database Manual: Methods Library; PReConsultants: Amersfoort, The Netherlands, 2008.

68. Guinée, J.B.; Lindeijer, E. Handbook on Life Cycle Assessment: Operational Guide to the ISO Standards; Springer Science \& Business Media: Dordrecht, The Netherlands, 2002; Volume 7.

69. von Bahr, B.; Hanssen, O.; Vold, M.; Pott, G.; Stoltenberg-Hansson, E.; Steen, B. Experiences of environmental performance evaluation in the cement industry. Data quality of environmental performance indicators as a limiting factor for Benchmarking and Rating. J. Clean. Prod. 2003, 11, 713-725. [CrossRef]

70. Panesar, D.K.; Seto, K.E.; Churchill, C.J. Impact of the selection of functional unit on the life cycle assessment of green concrete. Int. J. Life Cycle Assess. 2017, 22, 1969-1986. [CrossRef]

71. Hertwich, E.G. Consumption and the Rebound Effect: An Industrial Ecology Perspective. J. Ind. Ecol. 2005, 9, 85-98. [CrossRef] 